\title{
Factors influencing the willingness of Hungarian sour cherry growers to operate in a short supply chain
}

\author{
NOÉMI VÁNYI* (1) and JÁNOS FELFÖLDI
}

Institute of Applied Informatics and Logistics, University of Debrecen, Debrecen, Hungary

Received: February 6, 2021 • Revised manuscript received: May 28, 2021 • Accepted: June 11, 2021

Published online: September 2, 2021

(c) 2021 The Author(s)

\begin{abstract}
Although a number of studies have been conducted over the past decade to understand the factors influencing the willingness of producers to operate in a short supply chain (SSC), the intention to adapt can still be identified as an unexplored area. The main aim of the present study is to determine the extent to which Hungarian fresh sour cherry producers show a willingness to operate in a short supply chain and what investments they would make to do so. The sour cherry producers involved in the study clearly show a willingness to operate in a short supply chain. Some producers approach this in a "complex" manner, so they would even meet individual consumer needs and deliver orders to the consumer. Farmers opting for a "simpler" solution would prefer to sell their products to the consumer at their premises or at farmer's markets. Further results support the fact that the more producers believe in the viability and future of SSCs and the higher their level of education is, the more willing they are to adapt in terms of resources or production processes in order to achieve complete transition. The results reflect the importance of examining the factors that determine farmers' intentions to operate in the short supply chain, but it is also worthwhile and justified to explore how willing they are to "sacrifice" and invest in order to completely adapt.
\end{abstract}

\section{KEYWORDS}

short supply chain, business relationship, lead time, customer service, adaptation

\section{JEL CODES}

Q10, Q13, Q19

\footnotetext{
*Corresponding author. E-mail: vanyi.noemi@econ.unideb.hu
} 


\section{INTRODUCTION}

It is now accepted that competition occurs among supply chains in the market rather than among independent organizations (Lambert - Cooper 2000; Christopher 1998; Cox 1999). Conscious management of any supply chain is essential. In order to be successful, it requires efficiency and an orientation based on an acceptance by its actors that the entire chain will contribute to the effectiveness of a member organization. In other words, there is a basic need for a close, long-term relationship between the actors in the chain, embodied in mutual trust and commitment, enhanced information sharing and mutually beneficial business cooperation. Naturally, the more intermediaries there are between the producer and the consumer, the less chance there is for trust-building. Trust in such a business relationship is based on close contact and mutual sharing of information. Therefore, the further a producer is from the consumer in a supply chain, the more vulnerable that producer becomes to influences and misinformation of which he might not even be aware.

Producers with smaller farms have to operate in an intensely competitive market while meeting strict sales requirements. Multinational companies have marginalized producers, e.g. by sourcing cheaper produce far from the actual points of sale, thereby undercutting local producers unable to compete in terms of price, uniformity of produce or required amounts of product per order. More specifically, even if producers meet the conditions expected by retail chains (large quantities of homogeneous goods), they are often only able to sell their products at cost because of their weaker bargaining position. This situation is no different if the product reaches the consumer through another intermediary, even if producers find it difficult or impossible to assert their interests.

Short supply chains (SSCs) have become increasingly important. Although interest in certain forms of short supply chains has only grown in Hungary in the last decade, its spread in the northern states of the European Union, the United States and Japan is unquestionable and dates back several decades (Szabó 2014).

The motivation of producers to operate in a short supply chain is on the one hand materialistic in nature, as this ensures their independence from the intermediary (Falguieres et al. 2015), and allows them to sell their products at higher prices (Tudisca et al. 2015). On the other hand, producers intend to build a closer relationship with consumers - and not strictly with profit in mind. Producers find socio-cultural elements, such as trust, commitment, a sense of fairness and mutually beneficial cooperation to be vital to maintaining their local customer bases. Additionally, producers argue that it is vital to preserve local traditions, to protect local values, and to focus on sustainability in their production activities. All of these factor into the level of motivation for a producer to be willing to operate in a short supply chain (Kiss 2020; Dunay et al. 2018).

The potential of short supply chains and the benefits they provide are unquestionable. Over the past decade, a number of studies have been conducted to explore the willingness of producers to operate in a short supply chain (Benedek et al. 2018; Charatsari et al. 2018; Tudisca et al. 2015; Demartini et al. 2017, Adrian et al. 2005; Andrei et al. 2019; Woods et al. 2009; Lang 2010; Macias 2008). At the same time, if the producers decide to operate in a short supply chain, their activities will diversify, and their activities may be accompanied by investments and developments, the costs of which must also be borne alone. After all, if producers sell their products directly to the consumer, it is also their job to recognize and serve their needs as best 
they can. Simultaneously, producers must comply with strict food hygiene standards and be responsible for financing not only for production but also for product preparation, storage, order processing, transport and even marketing activities. Consequently, in addition to examining the level of willingness a producer might have to operate in a SSC, it is also necessary to study specifically what kinds of investments producers are willing to make to be able to join an SSC.

On this basis, the overall objective of the study is to determine the extent to which Hungarian sour cherry producers are willing to operate in a short supply chain and to make investments to this end. In order to achieve this, our sub-objectives are:

-mapping the business relations of sour cherry producers, identifying the participants in the chain from the side of a producer's customers and determining the lead time of the product to be produced;

-exploring the intention of producers to operate in an SSC and the willingness to make investments in order to actually join one;

-exploring the links between faith in a short supply chain faith and intention to make an investment;

-establishing links between customer service patterns/adaptation in the SSC to age and level of education.

\section{LITERATURE REVIEW}

There are several approaches to defining the short supply chain in the literature, but there is no universally accepted definition. However, the main criteria to provide an accurate and comprehensive picture of short supply chains can be identified.

The most important criteria for defining short supply chains are the number of intermediaries and the limitation of their number is present in numerous studies. The definition of the European rural development regulation (1305/2013) in this regard is a "limited number of economic operators". According to Renting et al. (2003), the number of intermediaries should be minimized between producer and consumer, ideally even omitting all of them. According to the FMAFF (2008), "commercialization of agricultural products through direct selling or indirect selling when only one intermediary is involved." Thus, one of the important and fundamental criteria for short supply chains is the small social distance between the producer and the consumer, according to which the number of intermediaries is minimized or ideally eliminated altogether.

Another important criterion of a short supply chain found in the literature is the close geographical relationship between producer and consumer (Parker 2005; The European rural development regulation (1305/2013); Peters 2012). A close geographical relationship between producer and consumer appears to be an important criterion for short supply chains, despite the lack of a clear consensus on its exact definition, as its optimal extent may vary due to regional and cultural diversity of food systems.

Social relations and knowledge exchange between producer and consumer are also mentioned as descriptive features of short supply chains (Jarzębowski et al. 2020, Ilbery - Maye 2005). Due to the small social and geographical distance, consumers get to know the producer 
better. A closer relationship is established between them and thus the consumer gains more information about the purchased product and its origin. In this way, trust, mutual respect and commitment to continue to do business with each other can develop, leading to consumer loyalty. According to Renting et al. (2003), such a relationship is supported by the consumer being able to accurately identify and trace the product being purchased.

Aspects of sustainability, including environmental, social, economic, health and well-being, also appear as characteristics of short supply chains (Galli - Brunori 2013). In terms of health and well-being, consumers can have access to a fresher product, thanks to shorter transport routes and storage times, which can reduce the nutrient loss of products (Frith 2007). Short supply chains may also have environmental sustainability benefits, such as the minimal use of packaging, less intensive production technology, or environmentally-friendly modes of transport. In terms of social sustainability, a mutually beneficial personal relationship based on trust and common values between the producer and the consumer helps consumers to understand the "real" costs of the product they purchase. Nevertheless, in addition to giving the producers a fair income for their work (Renting et al. 2003), it also means ethical recognition and esteem. Regarding the economic aspect, it should be noted that producers with small farm size and small volume are typically involved in a short supply chain (Jarosz 2008). When consumers become committed to the producer in the long run, they reduce producer uncertainty about production and sales, thereby contributing to improving the competitiveness and economic viability of producers (Galli - Brunori 2013).

The results of previous research demonstrate that producers on smaller farms are mainly those involved in short supply chains (Benedek 2014; Szabó 2014; Jarosz 2008, RDP 2009). Among the main factors determining the willingness of producers to operate in an SSC, several authors cite producer age and level of education (Marin et al. 2017, Andrei et al. 2019; Mojo et al. 2017; Adrian et al. 2005). The demographic characteristics of farmers and the results of studies on the propensity to operate in a SSC show that producers who operate in a short supply chain have a lower-than-average age (Andrei et al. 2019; Woods et al. 2009; Lang 2010; Macias 2008), and have higher levels of educational attainment (Andrei et al. 2019; Brunori et al. 2011; Lang 2010). Other factors influencing the willingness to operate in an SSC include the size of the land available to the farmer, and net benefit (Adrian et al. 2005), and family size, social networks (Mojo et al. 2017), cultivated area, year of establishment and opportunities to access financial support (Andrei et al. 2019).

\section{MATERIALS AND METHODS}

The main aim of our study is to explore the extent to which sour cherry growers selling fresh to the market show a willingness to operate in a short supply chain and what investments they would make to do so. We started our research by studying the relevant international and Hungarian literature. Following the secondary research, as a first step in the primary research, we conducted a producer brainstorming in December 2018 to create the foundation for the compilation of the questionnaire, which was attended by 25 Hungarian sour cherry growers.

The first part of the questionnaire typically included open-ended questions aimed at exploring general information about the structure, size, business habits and producers of their businesses, their qualifications and experience. In addition, the questions concerned their 
business relationships in the supply chain and the turnaround time of the fruit they produced. The second part of the survey already included the way in which farmers were served (hereinafter: customer service), where they had to assess which type of operation in the short supply chain and with what willingness they would choose. Subsequently, in the last question, the respondents assessed the readiness to adapt (hereinafter referred to as willingness to adapt/ invest), i.e. the extent to which they would be willing to invest in order to operate in a short supply chain. Claims about the willingness to adapt and the way of customer service had to be assessed by producers on a Likert scale of $1-5$. In both cases, the lowest value (1) represented the absolute contradiction, while the highest endpoint represented the complete agreement between which the respondents could place their opinion on the various statements (Allen - Seaman 2007).

The questionnaire survey was conducted in the form of "Paper and Pencil Interview" (PPI) between January and March 2019 (Tamus 2009). The subjects of the questionnaire were selected with a non-random sampling procedure using the snowball method, based on which the results cannot be considered representative (Brace-Govan 2004). The questionnaire survey was conducted in Hungary, including Szabolcs-Szatmár-Bereg County, which can be identified as the dominant sour cherry-producing area of the country.

Following the questionnaire survey, we had 117 completed questionnaires. Data processing and statistical analyses were performed using IBM SPSS Statistics 22.0 for Windows. As a first step in the evaluation of the results of the questionnaire, the aim was to classify the enterprises by size on the basis of the average annual number of employees and the net sales of the previous year taking Act XXXIV of 2004 into account, the law aimed at defining micro, small and mediumsized enterprises. Based on this, examining the distribution of the 117 questionnaires, it can be clearly stated that the vast majority of respondents were micro-entrepreneurs and a smaller proportion were small entrepreneurs. Yet, in order to ensure that the different size categories did not cause bias in the interpretation of the results, we filtered out small businesses, so we used 101 questionnaires for our study, each of which included responses from microenterprise owners.

To determine the internal consistency of the questionnaire, an item analysis was performed. When creating a new measuring instrument, reliability is one of the most important properties, because in the case of a new scale, we are interested in whether the items selected into a scale on a theoretical or empirical basis really belong to one scale. The procedure suitable for testing reliability is the so-called Cronbach's alpha calculation developed exclusively for this purpose. The Cronbach's alpha (coefficient) is basically a reliability indicator that can be calculated for summary scales, which expresses the internal consistency of the scale with a number between 0 and 1 . A value above 0.70 is considered acceptable: below this, the scale is not consistent enough. Cronbach's alpha values are lower for adaptive and direct selling propensity if an item in any scale is omitted (Cho - Chun 2018).

In order to explore the general socio-demographic questions related to producers and their current situation and to map the lead time, the average of the descriptive statistical methods and the minimum and maximum values representing the standard deviation were used. Evaluations of producer' customer service and willingness to adapt have been recalculated to a balance sheet index in order to make the positive and negative direction and extent of changes clear and wellunderstood. The value of the balance sheet index is a number between +100 and -100 . A value of one hundred means that the respondent gave a maximum value, i.e. a value of 5 , so the given statement is fully characteristic. A value below 0 already indicates a negative opinion. 
Among the structure exploration and verification methods, we used linear regression calculation, the aim of which is to select a group of variables from a large number of explanatory variables that mainly explain the fluctuation of the dependent or criterion variable (Horowitz Sokbae 2002). The aim is to understand the relationship between belief in viability in the short supply chain and developments to be made for SSC.

To understand the opinion of producers, we used factor analysis to reveal directly unobservable background variables (Horváth 2020). The age of the producers and the way of customer service/adaptation were compared in pairs with the Mann-Whitney $U$ test to see if there is a significant difference between them. Educational attainment and intent to service/ adapt were compared with the Kruskal-Wallis test (Malhotra 2009).

After completing and evaluating the questionnaire survey, we conducted a semi-structured interview with 22 sour cherry growers in the last part of the research. The reason for conducting the semi-structured interview was that the results of the brainstorming and the questionnaire revealed that farmers had very little information about the further route of the fruit produced and the lead time, so the in-depth interview provided a more thorough mapping and understanding of these issues.

The subjects of the professional in-depth interview were selected with a non-random sampling procedure using the snowball method, according to which new producers were selected for further interviews based on the suggestions of the respondents (Brace-Govan 2004). The farmers received the results of the primary research in advance, and then during the in-depth interview, they were enquired about the results of the research to see whether they agreed with them. The issues related to the lead time were clarified to them.

\section{RESULTS AND EVALUATION}

\subsection{Socio-demographic characteristics of respondents}

The results of the questionnaire survey show that the total area available to producers is on average 91 hectares, of which the average size crop land dedicated to sour cherries is $11 \mathrm{ha} .78 \%$ of the surveyed producers identified sour cherry growing as their main activity. The average age of the respondents is 49 years, the youngest producer is 20 years old and the oldest is 78 years old. The average experience of farmers in fruit production is 24 years, which is very high, so it can be stated that the producers who filled in the questionnaire have enough experience to participate in the research.

The gender distribution of respondents shows that the vast majority of respondents (93\%) were men. Regarding the highest educational attainment of producers, $1 \%$ have a doctorate, $28 \%$ have a college/university degree, $69 \%$ have a General Certificate of Secondary Education and 2\% have eight years of elementary education. $56 \%$ of respondents have some type of agricultural education. Based on all the orchard areas and the experience spent in production, we found that the producers have sufficient knowledge to participate in the research.

The area of sour cherries available to the producers participating in the semi-structured indepth interview is on average 16 ha and fruit production is uniformly their main activity. Their average age is 45 years and their experience in fruit production is 14 years. In terms of their educational attainment, 3 have a doctorate, 12 have a college/university degree and 7 completed eight years of primary education. All 22 producers have some type of agricultural education. 


\subsection{Examination of questionnaire reliability}

To determine the internal consistency of the questionnaire, an item analysis was performed. Based on the results, we found that each of the statements assigned to the 2 dimensions (customer service mode and willingness to adapt) fits well with the scales that measure it, and the reliability of the scales based on internal consistency is adequate (Table 1).

The propensity to adapt scale is made up of 11 statements with outstanding Cronbach's alpha values above 0.9 . The same can be said for the customer service method scale, to which 9 statements were assigned, and for each of them, the Cronbach's alpha value exceeds 0.8 . Since the Cronbach's alpha values of the factors are above 0.8 in all cases, it can be concluded that their reliability based on internal consistency is adequate.

\subsection{Exploring the current sales situation of producers}

The aim of the first part of the research was to identify the business relationships of the producers and to determine the lead time of the produced product based on the questionnaire survey and the in-depth interview. The results of the customer relationship exploration show that $56 \%$ of the respondents identified the intermediary trader as the most important customer relationship, and $28 \%$ identified the wholesale unit as the determining partner. Only $16 \%$ of the respondents named TÉSZ (Producer Sales Organization or PSO hereinafter) as the most important business relationship. After identifying the first-round customers, the aim was to identify further customers, i.e. to which the participant producer's customer resells the product. Thus, in order to fully map the supply chain, respondents had to identify additional chain members in the questionnaire. $46 \%$ of the producers surveyed unanimously identified the retail unit as a market player in the chain and the consumer as the final customer. However, more than half of the producers (54\%) were unable to track the further path of the fruit they produced. This means that these farmers do not receive further information about the product after the sale, not even through which intermediaries their product reaches the consumer. Another problem with the flow of information was raised by farmers during the in-depth interview. According to the unanimous response of farmers, they do not trust their customer and do not receive information on demand or market needs from either their customer or other participants in the chain. The reason for withholding information is seen in the fact that customers are deliberately kept in uncertainty, thus increasing their vulnerability and further worsening their bargaining position. It is also very common in their experience that although the buyer provides the producer with information about the market situation, in the opinion of farmers, this information mostly does not reflect the reality. In the experience of producers, even if they receive information from their customer, it usually relates to the conditions of sale, more specifically to its difficulty. In their view, this is not always the case. In this case, the clear purpose of the buyer is to destabilize the producer and weaken their bargaining position in the next transaction. Based on these, it can be concluded that not only the quantity of information but also its quality is important in business relationships.

Producers determined an average of 45 hours from the time the order was picked until the time it was sold to the buyer. The minimum value in this case was 1 hour, which means that the fruit is removed immediately after picking. The maximum value was 10 days, according to which the producer has some storage/cooling capacity, thus ensuring the quality protection of the product until delivery. After that, however, they no longer knew how much time the product 
Table 1. Method of customer service and statistical reliability of the willingness to adapt dimensions

\begin{tabular}{|l|l|}
\hline Dimensions & Cronbach alpha \\
\hline Method of customer service & 0.870 \\
\hline Intention to strengthen direct sales & 0.879 \\
\hline Presence in online producer database & 0.875 \\
\hline Sales to customer from site & 0.871 \\
\hline Transportation to producers' shops & 0.870 \\
\hline Sales at producer's market & 0.880 \\
\hline Serving aggregated orders from site & 0.883 \\
\hline Transport to central receiving site & 0.882 \\
\hline Serving individual needs in the case of a pre-placed order if the consumer picks it \\
up
\end{tabular}

Source: authors.

would spend at the other participants in the chain. The main reason for this is that most producers are not able to identify other actors in the chain, nor do those who know the buyer's customer have information on how long the resale process takes (Fig. 1).

Producers cited a lack of trust and commitment between actors (63\%) as a barrier to information sharing at the supply chain level. In addition, interpreting the issue at the producer level, their vulnerable situation due to dependence (27\%) was identified as the main obstacle to 


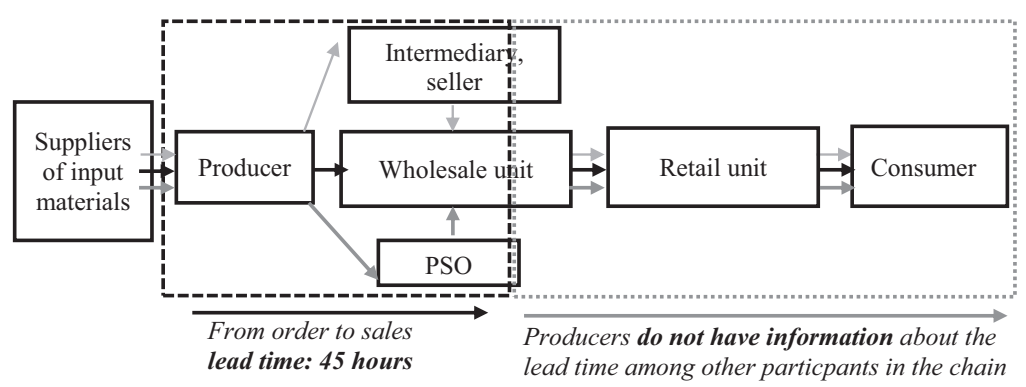

Fig. 1. Lead time among the participants of the supply chain Source: authors.

obtaining information. According to the unanimous opinion of the producers, in order for the harvested fruit to reach the customer as quickly as possible, so that there is no change in its freshness or content, a short supply chain is the solution (beyond the development of harvesting technology).

\subsection{Method of producers serving customers and their willingness to adapt}

In the next part of the research, we present the evaluation of the way of customer service, i.e. which of the sales methods prevalent in the short supply chain would be chosen by the producers with what willingness. Figure 2 is a good reflection of the fact that producers clearly have a positive view of the factors associated with short supply chain patterns and willingness. $51 \%$ of producers believe that they are willing to strengthen direct sales to consumers in their activities and $39 \%$ would do so in an online producer database to increase availability. $48 \%$ of respondents would even deliver to producer shops and $44 \%$ to a central point of sale, and $43 \%$ would even increase their presence and sales in producer markets, where the consumer would have easier access to their products.

Furthermore, $40 \%$ of the respondents were positive that they would be willing to sell from their farm to customers for their own consumption. Approximately half of the respondents (46\%), in case they do not have to deliver the crop, would even serve an aggregate order from their premises and 35\% would even assemble product baskets based on individual needs if the consumer shows up on-site. The possibility for producers to replace orders based on individual needs with customers has been explicitly rejected, with farmers being negative only in this case.

Looking at the evaluation of the producers' intention to adapt, we get a much more nuanced picture (Fig. 3). 28\% of respondents would be willing to sacrifice food security for the sake of a short supply chain, both in terms of money and learning. $24 \%$ of producers would be willing to make a major investment only in the production of raw materials and $23 \%$ only in the development of sales. Furthermore, $20 \%$ of farmers would be willing to make major adaptations to special tools and equipment as well. $12 \%$ of the respondents are also ready to expand the number of staff or to train the employees or themselves in the field of human resources. $10 \%$ of farmers would introduce new operating procedures and methods (e.g. sales support software, IT solutions) for the sake of the short supply chain. 


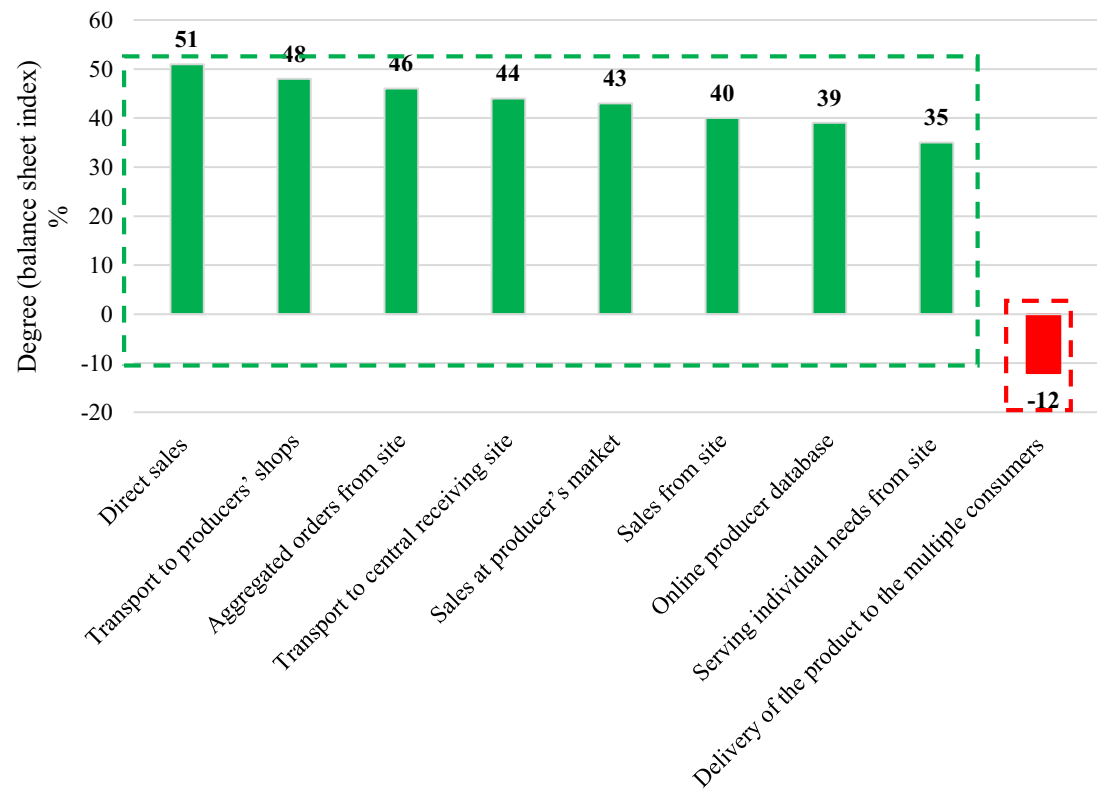

Factors of willingness to sell directly

Fig. 2. Evaluation of the willingness of producers to be assigned to customer service methods Source: authors.

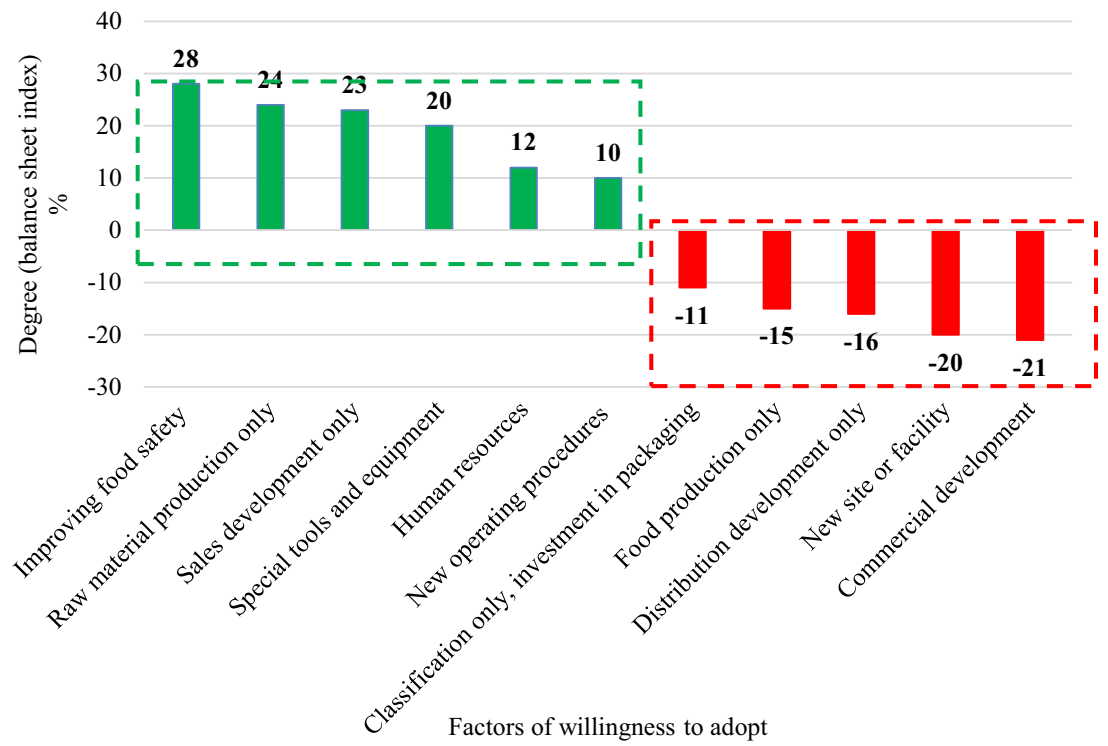

Fig. 3. Evaluation of the producer willingness to adapt Source: authors. 
Respondents, on the other hand, clearly reject the possibility of participating in commercial development, either by setting up or renovating a store $(21 \%)$ or by setting up a new premises (20\%) for direct sales. The development in distribution and distribution processes (16\%), investment in food production (15\%) and adaptation in classification and packaging (11\%) were also negatively assessed.

\subsection{The relationship between belief in the short supply chain and the development of activities}

In the next step, we looked for the answer to whether there is a correlation between how much the producer believes in the future of short supply chains and what activities he would be willing to develop in order to achieve this. For the latter, the following activities were assessed by the respondents: (1) Would make a significant improvement only in the production of raw materials; (2) Would make a significant improvement only in classification and packaging; (3) Would make a significant improvement only in food production; (4) Would make significant improvements only in distribution; (5) Would make significant development only in sales. A stepwise linear regression analysis was performed to explore the relationships. In the regression calculation, belief in the supply chain as a dependent variable and activities to be performed for the short supply chain were included in the analysis as independent variables. For this, the linear correlation between the dependent and independent variables expected at that time could be demonstrated. In our case, each independent variable is moderately positively related to the dependent variable (we obtained $r$ values between 0.47 and 0.6 ). There is no confounding multicollinearity between the independent variables, which is supported by the 1.326 VIF values obtained for both variables.

The summary table of the regression model (Table 2) shows that the resulting model explains $43 \%$ of the variance in belief in the supply chain (adjusted $R^{2}=0.427$ ).

The results in the ANOVA table show that the probability for test $\mathrm{F}$ is less than 0.05 , which confirms the existence of a relationship between the variables (Table 3).

The results so far and Table 4 show that there are only two influencing variables in the model, namely "investment in raw materials only" and "sales/sales development only".

The regression line is as follows:

$$
\begin{aligned}
\text { Belief in SSC }= & 0.767+0.389 * \text { raw material production development } \\
& +0.305 * \text { sales development }
\end{aligned}
$$

Based on this, it can be said that the more producers believe in the viability and future of short supply chains, the more they are willing to invest in raw material production in order to achieve this, and secondly, to improve their distribution and sales.

Table 2. Summary table of the regression model

\begin{tabular}{|c|c|c|c|c|}
\hline Model & R & R Square & Adjusted R Square & Std. Error of the Estimate \\
\hline 2 & 0.662 & 0.439 & 0.427 & 1.017 \\
\hline
\end{tabular}

Notes: Dependent: Fully believes in the viability of SSC. Predictors: (constant), would make a significant improvement only in the production of raw materials, would make a significant improvement only in sales

Source: authors. 
Table 3. ANOVA - table results (belief in short supply chains, development of activities)

\begin{tabular}{|l|c|c|c|c|c|}
\hline & Sum of Squares & \multicolumn{1}{c|}{ df } & Mean Square & F & Sig. \\
\hline Regression & 79.164 & 2 & 39.582 & 38.273 & 0.000 \\
\hline Residual & 101.351 & 98 & 1.034 & & \\
\hline Total & 180.515 & 100 & & & \\
\hline
\end{tabular}

Notes: Dependent: Fully believes in the viability of SSC. b Predictors: (constant), would make a significant improvement only in the production of raw materials, would make a significant improvement only in sales. Source: authors.

Table 4. The estimated regression coefficients

\begin{tabular}{|l|c|c|c|c|c|c|c|}
\hline \multirow{2}{*}{ Model } & \multicolumn{2}{|c|}{$\begin{array}{c}\text { Unstandardized } \\
\text { Coefficients }\end{array}$} & $\begin{array}{c}\text { Standardized } \\
\text { Coefficients }\end{array}$ & & & \multicolumn{2}{|c|}{$\begin{array}{c}\text { Collinearity } \\
\text { Statistics }\end{array}$} \\
\cline { 2 - 4 } \cline { 6 - 8 } & $\mathrm{B}$ & Std. Error & Beta & $t$ & Sig. & Tolerance & VIF \\
\hline (Constant) & 0.767 & 0.282 & & 2.719 & 0.008 & & \\
\hline $\begin{array}{c}\text { Would make a significant } \\
\text { improvement only in the } \\
\text { production of raw materials }\end{array}$ & 0.389 & 0.080 & 0.424 & 4.868 & 0.000 & 0.754 & 1.326 \\
\hline $\begin{array}{c}\text { Would make a significant } \\
\text { improvement only in sales }\end{array}$ & 0.305 & 0.078 & 0.340 & 3.902 & 0.000 & 0.754 & 1.326 \\
\hline
\end{tabular}

Note: Dependent Variable: Fully believes in the viability of SSC.

Source: authors.

\subsection{Differences in customer service methods and producer willingness to adapt}

In the following, we examine whether there is a difference in the way producers think about which short supply chain solution to choose and with what willingness. To explore this, we performed a factor analysis. We examined whether the chosen customer service methods belong together as short supply chain solutions based on the respondents' judgment. It can be stated that factor analysis can be definitely applied on the basis of the KMO and Barlett tests, as its value exceeded 0.8 (Table 5).

In order to determine the number of factors and to interpret the factors, it was necessary to rotate the factors, during which we chose the 2 -factor solution. Regarding the results, it can be stated that the 2 well-separated factors explain $66.7 \%$ of the cases well, so the respondents can be classified into 2 well-distinguished groups based on their thinking (Table 6).

Factor 1 has been termed "simple". This factor includes the solutions that producers would take and develop for the sake of the short supply chain, but can still be called simpler solutions compared to the second factor. These include delivering their products to producer shops or selling them from the premises to the consumer, either on a combined order basis or increasing 
Table 5. Result of KMO test regarding the method of customer service

\begin{tabular}{|c|c|c|}
\hline \multicolumn{2}{|c|}{ KM0 } & 0.847 \\
\hline \multirow{3}{*}{ Bartlett's Test of Sphericity } & Approx. Chi-Square & 468.332 \\
\cline { 2 - 3 } & $\mathrm{df}$ & 36 \\
\cline { 2 - 3 } & Sig. & 0.000 \\
\hline
\end{tabular}

Source: authors.

Table 6. Rotated component matrix regarding the method of customer senice

\begin{tabular}{|l|c|c|}
\hline \multirow{2}{*}{ Method of customer service } & \multicolumn{2}{c|}{ Factors } \\
\cline { 2 - 3 } & Simple & Complex \\
\hline Transportation to producers' shops & 0.830 & 0.240 \\
\hline Sales to customer from site & 0.781 & 0.220 \\
\hline Serving aggregated orders from site & 0.640 & 0.328 \\
\hline Sales at producer's market & 0.624 & 0.522 \\
\hline $\begin{array}{l}\text { Delivery of the product to the consumer, even to several locations, } \\
\text { taking individual needs into account }\end{array}$ & 0.090 & 0.899 \\
\hline $\begin{array}{l}\text { Serving individual needs in the case of a pre-placed order if the } \\
\text { consumer picks it up }\end{array}$ & 0.270 & 0.793 \\
\hline Transport to central receiving site & 0.372 & 0.608 \\
\hline
\end{tabular}

Source: authors.

their presence in producer markets. Factor 2 includes "complex" solutions. Here, they would already serve pre-placed orders based on individual needs and even place the fruit with customers, even if they need to be delivered to many places.

Since in the case of direct sales, the producer has to calculate with the costs incurred (transport, warehousing, marketing, etc.) being borne by them and, in addition, has to make even a major investment. Therefore, we also examined whether there is a difference in the way respondents think in terms of investment intentions for the sake of a short supply chain. To achieve this, we performed another round of factor analysis. As the value of the KMO indicator is above 0.8 in this case as well, based on the KMO criterion it can also be stated that the variables are suitable for further analysis (Table 7).

In order to determine the number of factors and to interpret the factors, it was still necessary to rotate the factors. In this case, too, the 2 -factor solution seemed to be a good solution, as so many factors explained the minimum $63 \%$ variance level in each case. The results show that the respondents can be classified into 2 well-distinguished factors even in the case of the willingness to adapt, based on their thinking (Table 8). 
Table 7. Result of KMO test regarding the willingness to adapt

\begin{tabular}{|c|c|c|}
\hline \multicolumn{2}{|c|}{ KM0 } & 0.847 \\
\hline \multirow{3}{*}{ Bartlett's Test of Sphericity } & Approx. Chi-Square & 468.332 \\
\cline { 2 - 3 } & df & 36 \\
\cline { 2 - 3 } & Sig. & 0.000 \\
\hline
\end{tabular}

Source: authors.

Table 8. Rotated component matrix regarding the willingness to adapt

\begin{tabular}{|l|c|c|}
\hline \multirow{2}{*}{} & \multicolumn{2}{|c|}{ Factors } \\
\cline { 2 - 3 } Investing in special tools and equipment & Resource & 0.286 \\
\hline Investing in new operating procedures and methods & 0.824 & 0.251 \\
\hline Investing in a new site or facility & 0.813 & 0.134 \\
\hline Investing in human resources & 0.789 & 0.463 \\
\hline Commercial development & 0.677 & 0.231 \\
\hline Classification only, investment in packaging & 0.671 & 0.111 \\
\hline Investing in food production only & 0.131 & 0.762 \\
\hline Investing in raw material production only & 0.371 & 0.713 \\
\hline Distribution development only & 0.350 & 0.643 \\
\hline Improving food safety & 0.547 & 0.564 \\
\hline
\end{tabular}

Source: authors.

The name of the 2 factors shows a very similar picture to the factors identified in the ways of customer service, which means that even in the case of the intention to adapt, two definite ways of thinking can be observed among the producers. Factor 1 has been dubbed "resource-minded," indicating that farmers in this factor tend to think about securing resources, approaching possible solutions for adaptation in this regard. Producers in this group would also make major investments in order to operate in a short supply chain. They are willing to either invest in new sites and operating procedures or special equipment, or even make significant improvements in human resources and trade.

Factor 2 includes "process-minded" producers who also show a willingness to adapt. In this group, respondents would rather only develop their activities for the short supply chain, such as classification-packaging, food production, distribution and in the field of raw material production.

\subsection{The intention to adapt as a function of age}

In the next part of the research, we sought the answer to whether there is a difference between the willingness of producers under 50 and over 50 to adapt using the smallest significant 
difference statistical analysis of the Mann-Whitney $U$ test. Statistical evaluation of the results of the studies was performed at the $\mathrm{p}=0.05$ significance level.

Although the results show that a difference in the mean was observed between the groups, they did not show a significant difference. Thus, it can be said that the willingness of producers to operate in a short supply chain is not differentiated according to age, so both younger and older producers have a similar intention to operate and invest in SSC.

Table 9. Average of Kruskal-Wallis test rankings in assessing willingness to adapt based on grouping of levels of education

\begin{tabular}{|c|c|c|c|c|}
\hline Adaptation factors & Level of education & $\mathbf{N}$ & Mean Rank & $\begin{array}{l}\text { Asymp. } \\
\text { Sig. }\end{array}$ \\
\hline \multirow{5}{*}{ Improving food safety } & $\begin{array}{c}\text { Eight years of elementary } \\
\text { education }\end{array}$ & 2 & 43.00 & \multirow{5}{*}{0.051} \\
\hline & $\begin{array}{c}\text { Secondary education / } \\
\text { GCSE }\end{array}$ & 70 & 46.18 & \\
\hline & College/university & 28 & 63.57 & \\
\hline & $\mathrm{PhD}$ & 1 & 52.50 & \\
\hline & Total & 101 & & \\
\hline \multirow{5}{*}{$\begin{array}{c}\text { Investing in special tools and } \\
\text { equipment }\end{array}$} & $\begin{array}{c}\text { Eight years of elementary } \\
\text { education }\end{array}$ & 2 & 69.50 & \multirow{5}{*}{0.011} \\
\hline & $\begin{array}{c}\text { Secondary education / } \\
\text { GCSE }\end{array}$ & 70 & 44.89 & \\
\hline & College/university & 28 & 63.84 & \\
\hline & $\mathrm{PhD}$ & 1 & 82.50 & \\
\hline & Total & 101 & & \\
\hline \multirow{5}{*}{$\begin{array}{l}\text { Investing in new operating } \\
\text { procedures and methods }\end{array}$} & $\begin{array}{c}\text { Eight years of elementary } \\
\text { education }\end{array}$ & 2 & 23.00 & \multirow{5}{*}{0.001} \\
\hline & $\begin{array}{c}\text { Secondary education / } \\
\text { GCSE }\end{array}$ & 70 & 44.52 & \\
\hline & College/university & 28 & 67.93 & \\
\hline & $\mathrm{PhD}$ & 1 & 86.50 & \\
\hline & Total & 101 & & \\
\hline \multirow{5}{*}{ Investing in a new site or facility } & $\begin{array}{c}\text { Eight years of elementary } \\
\text { education }\end{array}$ & 2 & 55.50 & \multirow{5}{*}{0.011} \\
\hline & $\begin{array}{c}\text { Secondary education / } \\
\text { GCSE }\end{array}$ & 70 & 45.10 & \\
\hline & College/university & 28 & 64.00 & \\
\hline & $\mathrm{PhD}$ & 1 & 91.00 & \\
\hline & Total & 101 & & \\
\hline
\end{tabular}

Source: authors. 


\subsection{The intention to adapt as a function of education}

In the following, we examined whether the respondents' educational levels influenced the willingness to adapt using the Kruskal - Wallis test. Based on the results, it can be concluded that there is a difference between the groups in the rank averages, and the Kruskal - Wallis test gave a significant result in the four categories, i.e. there is a significant difference between the groups in the assessments given for these questions (Table 9).

The results in Table 9 show that tertiary and doctoral producers are more willing to sacrifice for the sake of the short supply chain: they would also invest in food safety, new operating procedures and methods, the construction of new sites and facilities, and special tools and equipment. Thus, in terms of educational attainment, more skilled producers are more likely to be willing to make major investments in order to operate in the short supply chain.

\section{CONCLUSIONS AND RECOMMENDATIONS}

The sour cherry producers included in the study are uniformly the owners of micro-enterprises which operate in Szabolcs-Szatmár-Bereg County of Hungary. For the vast majority of them, fruit production is their main profile. The aim of the study was to explore the current sales relationships of these fruit growers and to map the intention to operate and adapt in the short supply chain. The most important business partner of the interviewed producers is clearly the intermediary trader. They are followed by the wholesale unit and finally the PSO. The situation of cherry growers in their current business relationships can be characterized by vulnerability and mistrust. All this is coupled with the transfer of limited information from the customer side, both on consumer needs, market trends and further sales, thus increasing the precarious situation of producers. As a solution to this current hopeless situation, producers have unanimously identified operation in the short supply chain.

Producers would prefer direct sales, especially when operating in a short supply chain. Producers can basically be divided into 2 groups based on their thinking about the way they serve customers. On the one hand, those who choose the "complex" solution, would even serve pre-placed orders based on individual needs and even deliver the fruit to customers, even if they need to be delivered to different locations. The other group is made up of farmers who opt for a "simpler" solution, preferring to deliver their products to producer shops or to sell their products to the consumer from their premises or at producer markets.

Producers clearly believe that short supply chains have relevance and a future. The results show that the more they believe in the viability and future of SSCs, the more they are willing to invest in raw material production and improve their sales and sales to achieve this. In this case, too, the producers are divided into two groups based on their thinking. "Resource-minded people" tend to think about securing resources and would also make major investments in order to operate in a short supply chain. The other group is made up of "process-minded" producers who also show a willingness to adapt, but would rather only develop their activities for the sake of a short supply chain.

The results show that the propensity to adapt to the short supply chain of the producers involved in the study is not influenced by age, so it cannot be said that the younger or older generation would be more reluctant to support or support investments or developments in SSC. With regard to education, however, it is clear that those with higher education would make 
significant investments in order to operate in a short supply chain, whether in food security, new operating procedures and methods, the construction of new sites and facilities, and special tools and equipment.

The results reflect the fact that it is extremely important to examine which factors determine the intention of farmers to operate in the short supply chain, but it is also worthwhile and justified to explore their willingness to invest in order to achieve this. Thus, a thorough knowledge and understanding of adaptation intent must be an essential part of future research to fully map operations in short supply chains.

\section{ACKNOWLEDGEMENT}

The publication is supported by the Debrecen Venture Catapult Program, EFOP-3.6.1-162016-00022 project. The project is co-financed by the European Union and the European Social Fund.

\section{REFERENCES}

Adrian, A. M. - Norwood, S. H. - Mask, P. L. (2005): Producers' Perceptions and Attitudes Toward Precision Agriculture Technologies. Computers and Electronics in Agriculture 48(3): 256-271.

Allen, E. - Seaman, C. (2007): Likert Scales and Data Analyses. Quality Progress 40: 64-65.

Andrei, J. V. - Ion, R. A. - Chivu, L. - Pop, R. E. - Marin, A. (2019): Investigations on Farmers' Willingness to Associate and Join in Environmental Responsible Short Supply Chain in Romania. Applied Ecology and Environmental Research 17(2): 1617-1639.

Benedek Z. (2014): A rövid ellátási láncok hatásai - Összefoglaló a nemzetközi szakirodalom és a hazai tapasztalatok alapján [Impacts of Short Supply Chains - Summary Based on International Literature and Domestic Experience]. MTA-KRTK KTI Mühelytanulmányok MT-DP 2014/8.

Benedek, J. - Török, I. - Máthé, Cs. (2018): Evidence-based Designation of Development Regions in Romania. Regional Statistics 8(1): 120-140.

Brace-Govan, J. (2004): Issues in Snowball Sampling: The Lawyer, the Model and Ethics. Qualitative Research Journal 4(1): 52.

Brunori, G. - Rossi, A. - Malandrin, V. (2011): Co-producing Transition: Innovation Processes in Farms Adhering to Solidarity-based Purchase Groups (GAS) in Tuscany, Italy. International Journal of Sociology of Agriculture and Food 18: 28-53.

Charatsari, C. - Kitsios, F. - Stafyla, A. - Aidonis, D. - Lioutas, E. D. (2018): Antecedents of Farmers' Willingness to Participate in Short Food Supply Chains. British Food Journal 120(10): 2317-2333.

Cho, E. - Chun, S. (2018): Fixing a Broken Clock: A Historical Review of the Originators of Reliability Coefficients Including Cronbach's Alpha. Survey Research 19(2): 23-54.

Christopher, M. (1998): Logistics and Supply Chain Management: Strategies for Reducing Cost and Improving Service. London: Financial Times and Pitman Publishing.

Cox, A. (1999): Power, Value and Supply Chain Management. Supply Chain Management: An International Journal 4(4): 167-175.

Demartini, E. - Gaviglio, A. - Pirani, A. (2017): Farmers' Motivation and Perceived Effects of Participating in Short Food Supply Chains: Evidence from a North Italian Survey. Agricultural Economics (Zemědělská Ekonomika) 63(5): 204-216. 
Dunay, A. - Lehota, J. - Mácsai, É. - Illés, B. Cs. (2018): Short Supply Chain: Goals, Objectives and Attitudes of Producers. Acta Polytechnica Hungarica 15(6): 19.

Falguieres, M. - Kumar, V. - Garza-Reyes, J. A. - Kumari, A. - Lim, M. K. - Rocha-Lona, L. (2015): Investigating the Impact of Short Food Supply Chain on Emigration: A Study of Valencia Community in Spain. IFAC-PapersOnLine 28(3): 2226-2232.

FMAFF (2008): Strengthen the Link between Farmers and Consumers. Action Plan to Develop Short Circuits. French Ministry of Agriculture, Food and Forestry (FMAFF). http://agriculture.gouv.fr/IMG/ pdf/100809-lettreCircuitsCourts.pdf, accessed 15/06/2021.

Frith, K (2007): Is Local Food More Nutritious? It Depends. http://chge.med.harvard.edu/resource/localmore-nutritious, accessed 15/06/2021.

Galli, F. - Brunori, G. (2013): Short Food Supply Chains as Drivers of Sustainable Development. Evidence Document Developed in the Framework of the FP7 Project FOODLINKS.

Horowitz, J. L. - Sokbae L. (2002): Semiparametric Methods in Applied Econometrics: Do the Models Fit the Data? Statistical Modelling 2(1): 3-22.

Horváth, P. (2020): Az agrár- és vidékfejlesztési támogatások megítélése és hatása a Dél-alföldi Régióban [Assessment and Impact of Agricultural and Rural Development Subsidies in the Southern Great Plain Region]. Economica 11(3-4): 11-16.

Ilbery, B. - Maye, D. (2005): Alternative (Shorter) Food Supply Chains and Specialist Livestock Products in the Scottish-English Borders, Environment and Planning A 37: 823-844.

Jarosz, L. (2008): The City in the Country: Growing Alternative Food Networks in Metropolitan Areas. Journal of Rural Studies 24: 231-244.

Jarzębowski, S. - Bourlakis, M. - Bezat-Jarzębowska, A. (2020): Short Food Supply Chains (SFSC) as Local and Sustainable Systems. Sustainability 12: 4715.

Kiss, K. (2020): A rövid élelmiszerlánc (RÉL) szerepe a budapesti agglomeráció és Heves megye hagyományos és termelöi piacain [The Role of the Short Food Chain (SFC) in the Traditional and Producer Markets of the Budapest Agglomeration and Heves County]. Gödöllő: Szent István Egyetem, Gazdálkodás- és Szervezéstudományok Doktori Iskola.

Lambert, D. M., - Cooper, M. (2000): Issues in Supply Chain Management. Industrial Marketing Management 29(1): 65-83.

Lang, K. B. (2010): The Changing Face of Community-Supported Agriculture. Culture \& Agriculture 32: $17-26$.

Macias, T. (2008): Working Toward a Just, Equitable, and Local Food System: The Social Impact of Community-Based Agriculture. Social Science Quarterly 89: 1086-1101.

Malhotra, N. K. (2009): Marketingkutatás [Marketing Research]. Budapest: Akadémiai Kiadó Zrt.

Marin, A. - Ion, R. A. - Chetroiu, R. - Iurchevici, L. (2017): Designing and Experimenting Models for the Development of Short Chains for Fruit Production. Bucharest: Editura ASE.

Mojo, D. - Fischer, C. - Degefa, T. (2017): The Determinants and Economic Impacts of Membership in Coffee Farm Cooperatives: Recent Evidence from Rural Ethiopia. Journal of Rural Studies (50): 84-94.

Parker, G, (2005): Sustainable Food? Teikei, Co-operatives and Food Citizenship in Japan and in the UK. Working Paper in Real Estate and Planning 11/05.

Peters, R. (2012): Local Food and Short Supply Chains. EU Rural Review 12.

RDP (2019): Magyarország 2014-2020. évi vidékfejlesztési programjának adatlapja [Fact Sheet for the 2014-2020 Rural Development Program (RDP) of Hungary]. https:/ec.europa.eu/info/sites/info/files/ food-farming-fisheries/key_policies/documents/rdp-factsheet-hungary_hu.pdf, accessed 15/06/2021. 
Renting, H. - Marsden, T. K. - Banks, J. (2003): Understanding Alternative Food Networks: Exploring the Role of Short Food Supply Chains in Rural Development. Environment and Planning A 35(3): 393-411.

Szabó, D. (2014): A rövid ellátási láncban rejlő lehetőségek és veszélyek Magyarországon [Opportunities and Threats in the Short Supply Chain in Hungary]. Acta Carolus Robertus 4(2): 1-9.

Tamus, A. (2009): A marketingkutatás gyakorlata [The Practice of Marketing Research]. Gyöngyös: Károly Róbert Kutató - Oktató Közhasznú Nonprofit Kft.

Tudisca, S. - Di Trapani, A. M. - Sgroi, F. - Testa, R. (2015): Socio-economic Assessment of Direct Sales in Sicilian Farms. Italian Journal of Food Science 27(1): 101-108.

Woods, T. - Ernst, M. - Ernst, S. - Wright, N. (2009): Survey of Community Supported Agriculture Producers. University of Kentucky Agricultural Economics Extension Series 2009-11.

Open Access. This is an open-access article distributed under the terms of the Creative Commons Attribution 4.0 International License (https://creativecommons.org/licenses/by/4.0/), which permits unrestricted use, distribution, and reproduction in any medium, provided the original author and source are credited, a link to the CC License is provided, and changes - if any - are indicated. (SID_1) 